\title{
ESTABLISHMENT OF AN ARBORETUM (BOTANICAL GARDEN) OF WESTERN GHATS AT PILIKULA NISARGADHAMA WITH SPECIAL REFERNCE TO ENDEMIC AND THREATENED PLANTS AS AN EX-SITU CONSERVATION MEASURE
}

\author{
RAMAKRISHNA MARATI* \& H.S. SHENOY
}

Dr. Shivarama Karantha, Pilikula Nisarga Dhama, Vamanjoor, Mangalore, Karnataka, India

\section{ABSTRACT}

An arboretum is a special type of Botanical Garden meant for conserving arborescent species (= trees and shrubs). Pilikula Arboretum is one such Botanical Garden established in 35 ha of land in Mangaluru, Dakshina Kannada District of Karnataka, India. A total of about 60,000 plants belonging to 250 species of trees \& shrubs of the Western Ghats region are conserved in this Arboretum. This list includes 77 endemic species of Western Ghats, 14 threatened, one newly reported, and two rediscovered. This list also includes 4 monotypic genera. Pilikula arboretum is exclusively meant for conserving the plant species of the Western Ghats region of Karnataka state. This is a good example of an example of ex-situ conservation of plants.

KEYWORDS: The Western Ghats, arboretum, Pilikula Nisarga Dhama, ex-situ conservation, endemic, threatened, monotypic

Received: Sep 04, 2020; Accepted: Sep 24, 2020; Published: Nov 06, 2020; Paper Id.: IJBRDEC20207

\section{INTRODUCTION}

As per the Biological Diversity is concerned, India is one of the richest countries in the world. Based on the overall species richness, India has got a place in the 17 megadiverse countries of the world. Many cultivated plants were originated in this country and thus its richness concerning agro-biodiversity is very impressive. Western Ghats harbour many endemic and threatened species. Endemic species are those with restricted distribution and hence are extinction-prone. The word "endemism" means the confinement of an organism to a particular geographical location or locations; in other words, they survive in only such places where the type of ecosystem prevails. Since the species are distributed in the smaller the area, they are facing greater the threat, particularly if their habitats are disturbed. The Western Ghats which is recognised as one of the 35 globally recognised hotspots, namely India - Sri Lanka hotspot (www.conservation.org). If the organisms are destroyed in their location, they will be eliminated once for all from the earth. Hence hotspots are considered as the area of high conservation priority. That's why the Hotspots play a vital role in conserving the Biological Diversity of the World.

Western Ghats harbour a total of 7,402 vascular plant species (Nayar et al 2014). Singh et al (2015) reported 2116 species of endemic plants in the Western Ghats. About 80 endemic plant genera have a single species (monotypic genera) and some have many species, for example, the genus Strobilanthes is having 44 species; nearly $70 \%$ of the endemic genera monotypic. Since these genera having single species, if that single species is lost, the entire genus will vanish from the world. 
Some of the genera of Western Ghats are represented by large numbers of endemic species. Examples, Impatiens 76 out of 86 species are endemic, Dipterocarpus - 12 out of 13 species are endemic, and Calamus - 23 of 25 species are endemic. A total of 308 species out of 490 tree species recorded from low- and mid-elevation forests are endemic. Among the 267 species of orchids recorded from the Western Ghats, 130 are endemic to this region. The single gymnosperm tree species, Podocarpuswallichianus is also endemic to the Western Ghats.

Western Ghats region is a source of economically important species. It is thus an area with very high priority from the conservation point of view.

Destructive anthropic activities have taken a heavy toll of the forests of Western Ghats. The chief among them is the cultivation of exotic plant species like Acacia and Eucalyptus species, monoculture forest tree species like teak and plantations of commercial crops like coffee, tea, rubber and cocoa. Spices such as cardamom, clove and cinnamon are also cultivated at the cost of forests. Other activities like mining, river valley projects, fuelwood gathering, overgrazing, and forest fire and timber extraction have also contributed to the loss of forests.

Endemic species are found in a very restricted area and they require a special niche for their survival. If their habitat is disturbed, they may become endangered. Most of the endemic species are extinction prone because of they may have narrow geographical range, they have been having only one or a few populations; small population or little genetic variability; declining population; low reproductive potential or they be overexploited by the people etc.

About one-third of the endemic species of the Western Ghats are endangered and many species are believed to be extinct or on the verge of becoming extinction. Examples, Buchanania barberi Gamble (Anacardiaceae); Hopea jacobi C.E.C.Fisch (Dipterocarpaceae); Nothopegia aureo-fulva Beddome ex Hook.f. (Anacardiaceae); Cynometra beddomei Prain (Fabaceae); Dialium travancoricum Bourd. (Fabaceae); Eugenia singampattiana Beddome (Myrtaceae); Syzygium bourdillonii (Gamble) Rathakr. \& Nair (Myrtaceae); Syzygium courtallense (Gamble) Alston (Myrtaceae); Syzygium microphyllum Gamble (Myrtaceae); Syzygium palghatense Gamble (Myrtaceae); Syzygium travancoricum Gamble (Myrtaceae); Madhuca insignis (Radlk.) H.J.Lam (Sapotaceae); Actinodaphne bourneae Gamble (Lauraceae), and Pseudoglochidion anamalayanum Gamble (Euphorbiaceae).

Ex-situ conservation is the best-suited method to conserve the Biological Diversity in the wild. But due to persisting threats to the flora from various anthropogenic activities, it may not always be practical to conserve the species. Hence ex-situ conservation may sometimes prove to be an effective alternative to in situ conservation. One of the best examples of ex situ plant conservation is the establishment of Botanical Gardens. Thesegardens play a key role in plant conservation particularly endemic and threatened ones.

\section{ARBORETUM (BOTANICAL GARDEN) AT PILIKULA}

With the financial assistance from Indo-Norwegian Environment Program (INEP), an arboretum (Botanical Garden) extending over an area of about 85 acres has been established in Pilikula Nisarga Dhama, Mangaluru, Karnataka during 2000-2004, for conserving plant species of the Western Ghats region of Karnataka. Before planting this area was under Acacia and Casuarina cultivation. 


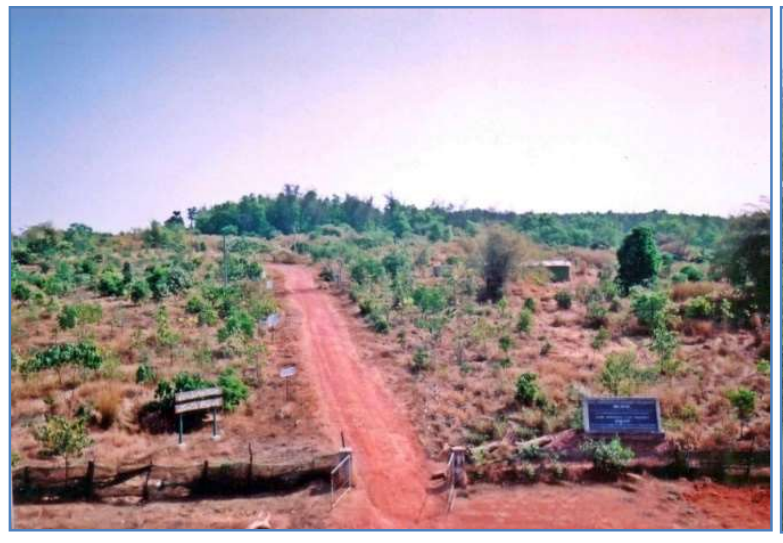

View of the arboretum in 2003

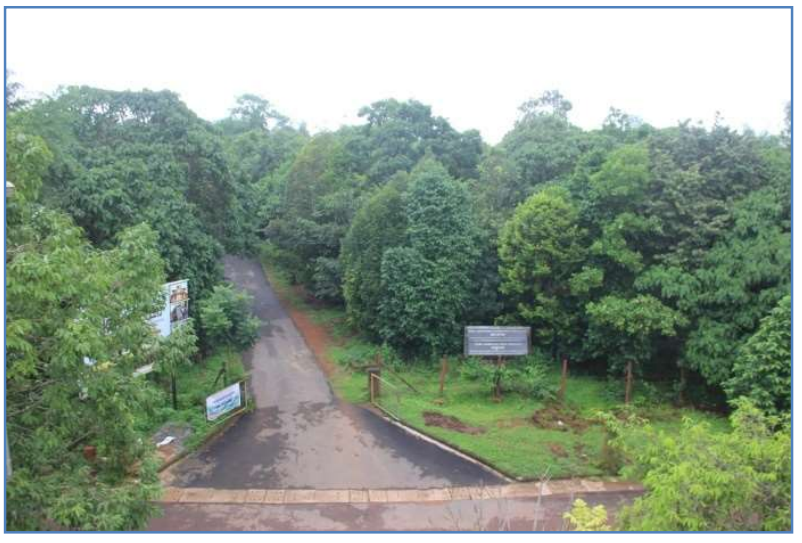

Present view of the arboretum

A total of 250 species belonging to 60 families have been introduced in the arboretum. Among them 77 species are endemic to the Western Ghats, 14 are threatened, four monotypic genera, one newly reported and three rediscovered species (Appendix 1).

\section{DISCUSSIONS}

The threatened endemic trees species introduced in the arboretum are Calophyllum apetalum Willd. (Clusiaceae), Dipterocarpus indicus Bedd. (Dipterocarpaceae), Garcinia indica (Thouars) Choisy(Clusiaceae), Gymnacranthera canarica (King) Warb. (Myristicaceae), Hopea canarensis Hole (Dipterocarpaceae), Hydnocarpus pentandrus (Buch.Ham.) Oken(Achariaceae), Kingiodendron pinnatum (DC.) Harms(Leguminosae), Myristica magnifica Bedd.(Myristicaeae), Myristica malabarica Lam.(Myristicaeae), Ochreinauclea missionis (Wall. ex G.Don) Ridsdale(Rubiaceae), Saraca asoca (Roxb.) Willd. (Leguminosae), and Vateria indica L. (Dipterocarpaceae). The list also includes rediscovered species like Madhuca insignis (Radlkofer) H.J. Lam (rediscovered after 120 years by Krishna Kumar et al, 2004);Syzygium kanarense (Talbot) Raizada(rediscovered after 50 years by Shenoy et al, 2015); and newly reported species like Syzygium travancoricum Gamble (New report to Karnataka by Krishna Kumar and Shenoy2006).

In addition to this, the following monotypic genera (Uniyal and Mathur 1994) are also introduced in the arboretum. These genera have single species and are endemic to the Western Ghats.

Blepharistemma Waliich ex Benth. (Rhizophoraceae)

B. serratum (Dennst.) Suresh

Otonephelium Radlk. (Beddome) Radlk. (Sapindaceae)

O.stipulaceum (Beddome) Radlk.

The monotypic genus Moullava Adans. with single speciesspicata (Dalz.) Nicolson (Fabaceae) earlier considered as endemic to India, but now it has lost its endemic status with extended distribution (Nayar et al 2014). And another monotypic genus Erinocarpus with single species nimmonii is also non-endemic to the Western Ghats.

It is also interesting to note that, the arboretum also has endemic palms and canes like Arenga wightii Griffith, Pinanga dicksonii (Roxb.) Blume, Calamus hookerianus Becc., C. karnatakensis Renuka \& Lakshmana, C. lakshmanae Renuka, C. nagabettai Fernandez \& Dey,C. prasinus Lakshmana \& Renuka, C. travancoricus Beddome ex Becc. \& Hook. 
f., C. vattayila Renuka.

The endemic climbers like Combretum razianum K.G.Bhat, Kunstleria keralensis C.N. Mohanan \& Nair, Spatholobus purpureus Benth. ex Baker andVentilago bombaiensis Dalz. are also introduced in the arboretum.

Many endemic species in the arboretum are economically important in one or more ways. For example, plants yielding timber (Dipterocarpus indicus Beddome, Artocarpus hirsutus Lam., Calophyllum apetalum Willd., H. parviflora Beddome, Kingiodendron pinnatum (DC.) Harms, Lagerstroemia microcarpa Wight, Poeciloneuron indicum Beddome, Polyalthia fragrans (Dalz.) Beddome, Syzygium laetum (Buch.-Ham.) Gandhi,Syzygium travancoricum Gamble and Vateria indica L.) plants used for weaving baskets, for making furniture and in handicrafts (Calamus nagabettai Fernandez \& Dey, Calamus prasinus Lakshmana \& Renuka, Ochlandra scriptoria (Dennst.) C. Fischer and O.travancorica Benth. ex Gamble); plants yielding gums and resins (Garcinia gummi-gutta (L.) N. Robson, H.ferruginea Marchand, H.grahamii (Wight) Kurz, H.nigra Bourd., Vateria indica L.); plants yielding paper pulp (Ochlandra scriptoria (Dennst.) C. Fischer and O.travancorica Benth. ex Gamble); plants yielding edible fruits (Artocarpus hirsutus Lam., Baccaurea courtallensis Muell.-Arg., Garcinia indica (Thouars) Choisy, Flacourtia montanaGraham and Syzygium laetum (Buch.-Ham.) Gandhi) and plants having medicinal importance (Hydnocarpus pentandrus (Buch.-Ham.) Oken, Memecylon malabaricum (C.B. Clarke) Cogn. etc.).

\section{CONCLUSIONS}

Arboreta (Botanical Gardens) play a vital role in the ex-situ conservation of endangered and endemic plant species as they serve readymade constituency for conservation. The ex-situ conservation of some of the endemic and threatened plants of the Western Ghats of Karnataka in the arboretum will not only help in educating the people, particularly the student community, about the diversity of plants in the Western Ghats and the need to conserve them but can also serve as source material for micro-propagation of rare and threatened plants

\section{ACKNOWLEDGEMENT}

The authors are grateful to Indo-Norwegian Environment Program (INEP) authorities for sponsoring the project during the period 2000-2004; to Prof. K. M. Kaveiappa, former Vice-Chancellor of Mangalore University; Late Mr. B.V. Shetty, former Deputy Director, BSI, Coimbatore; Executive Director of Pilikula Nisarga Dhama and project team.

\section{REFERENCES}

1. Goel, A.K. (2002). Ex situ conservation studies on some rare, endangered and endemic plant species at NBRI Botanic Garden. Indian Journal of Forestry, Vol. 25 (1): 67-78.

2. Kani, ISIK (2011). Rare and endemic species: why are they prone to extinction?. Turk. J. Bot. 35 (2011): 411-417

3. Krishna Kumar, G., H.S. Shenoy and K.M. Kaveriappa (2004). Rediscovery ofMadhucainsignis (Radlkofer) H.J.Lam. (Sapotaceae): A critically Endangered species of the Western Ghats, India. Phytomorphology 54 (3\&4): 209-213.

4. Krishna Kumar, G., H.S.Shenoy(2006).Syzygium travancorium Gamble, a new record to Karnataka. J.Eco \& Taxo.Bot.30(4):900-902.

5. Nayar, T.S. , A. Rasia Beegam and M.Sibi (2014). Flowering plants of Western Ghats, India, Volume 1 Dictots. Jawaharlal Nehru Tropical Botanical Botanical Garden. Pp.: 933

6. Singh P., Karthigeyan K., Lakshminarasimhan P., Dash S.S. (2015). Endemic Vascular Plants of India. Botanical Survey of 
India, Pp.: 339

7. Shenoy, H.S., G. Krishnakumar \& Ramakrishna Marati (2015). Rediscovery of Syzygium kanarense (Talbot) Raizada (Myrtaceae) - an endemic species of the Western Ghats, India. Journal of Threatened Taxa 7(1): 6833-6835

8. Shetty, B.V. and K.M. Kaveriappa (2001). An arboretum of endemic plants of Western Ghats at Mangalore University campus, Karnataka, India. March 2001 Zoos' Print Journal16(3): 431-438

9. Uniyal. B.P. and R. Mathur (1995). Monotypic genera of Angiosperms in Indian flora need for conservation. Bull. Bot. Surv. India, Vol. $36(1-4): 169-177$

10. http://www.conservation.org/where/priority_areas/hotspots/Pages/hotspots_main.aspx

11. https://www.iucnredlist.org/species

12. Malik, MUSHTAQ AHMAD, et al. "Rheum emodi as valuable medicinal plant." Intern J General Medic Pharmacy 5.4 (2016): $35-44$.

13. Kalimuthu, K., and R. Prabakaran. "In vitro flowering from nodal explants of Ceropegia pusilla Wight and Arn." Int J Bot Res 3.3 (2013): 35-42.

14. De, L. C., and D. R. Singh. "Natural resources in North East region of India." International Journal of Agricultural Science and Research 7.5 (2017): 51-66.

15. Kalimuthu, K., T. Sasikala, and R. Prabakaran. "Regeneration of multiple shoot from callus in Boucerosia truncato-coronata (Sedw.) Gravely \& Mayur." Int. J. Biotech. Res 3.3 (2013): 53-60.

\section{Appendix 1: List of plant species introduced in the Arboretum}

\begin{tabular}{|c|c|c|c|}
\hline Sl. No & Name of the species & Family & Conservation status \\
\hline 1. & Actinodaphne malabarica Balakr. & LAURACEAE & Endemic to W. Ghats \\
\hline 2. & Arenga wightii Griffith & PALMAE & Endemic to W. Ghats \\
\hline 3. & Artocarpus hirsutus Lam. & MORACEAE & Least Concern (IUCN) \\
\hline 4. & Baccaurea courtallensis Muell.-Arg. & EUPHORBIACEAE & Endemic to W. Ghats \\
\hline 5. & Blepharistemma serratum (Dennst.) Suresh & RHIZOPHORACEAE & Endemic, Monotypic \\
\hline 6. & Calamus hookerianus Becc. & PALMAE & Endemic to W. Ghats \\
\hline 7. & Calamus karnatakensis Renuka \& Lakshmana & PALMAE & Endemic to W. Ghats \\
\hline 8. & Calamus lakshmanae Renuka & PALMAE & Endemic to W. Ghats \\
\hline 9. & Calamus nagabettai Fernandez \& Dey & PALMAE & Endemic to W. Ghats \\
\hline 10. & Calamus prasinus Lakshmana \& Renuka & PALMAE & Endemic to W. Ghats \\
\hline 11. & $\begin{array}{l}\text { Calamus travancoricus Beddome ex Becc. \& } \\
\text { Hook. f. }\end{array}$ & PALMAE & Endemic to W. Ghats \\
\hline 12. & Calamus vattayila Renuka & PALMAE & Endemic to W. Ghats \\
\hline 13. & Calophyllum apetalum Willd. & CLUSIACEAE & Vulnerable (IUCN) \\
\hline 14. & Cinnamomum malabatrum (Burm.f.) Blume & LAURACEAE & Endemic to W. Ghats \\
\hline 15. & Combretum razianum K.G.Bhat & COMBRETACEAE & Endemic to W. Ghats \\
\hline 16. & Croton malabaricus Beddome & EUPHORBIACEAE & Endemic to W. Ghats \\
\hline 17. & Diospyros bourdillonii Brandis & EBENACEAE & Endemic to W. Ghats \\
\hline 18. & Dipterocarpus indicus Beddome & DIPTEROCARPACEAE & Endangered (IUCN) \\
\hline 19. & Dysoxylum malabaricum Beddome ex Hiern & MELIACEAE & Endangered (IUCN) \\
\hline 20. & Ensete superbum (Roxb.) Cheesman & MUSACEAE & Endemic to W. Ghats \\
\hline 21. & Epiprinus mallotiformis (Muell.-Arg.) Croizat & EUPHORBIACEAE & Endemic to W. Ghats \\
\hline 22. & Erinocarpus nimmonii J.Graham & TILIACEAE & Monotypic, Non-endemic \\
\hline 23. & Flacourtia montana Graham & FLACOURTIACEAE & Endemic to W. Ghats \\
\hline 24. & Garcinia gummigutta (L.) N. Robson & CLUSICAEAE & Endemic to W. Ghats \\
\hline 25. & Garcinia indica (Thouars) Choisy & CLUSICAEAE & Vulnerable (IUCN) \\
\hline 26. & Garcinia talbotii Raiz. \& Sant. & CLUSICAEAE & Endemic to W. Ghats \\
\hline 27. & Glochidion ellipticum Wight & EUPHORBIACEAE & Endemic to W. Ghats \\
\hline
\end{tabular}




\begin{tabular}{|c|c|c|c|}
\hline 28. & Glochidion johnstonei Hook. f. & EUPHORBIACEAE & Endemic to W. Ghats \\
\hline 29. & Gordonia obtusa Wallich ex Wight \& Arn. & THEACEAE & Endemic to W. Ghats \\
\hline 30. & Grewia heterotricha Masters & TILIACEAE & Endemic to W. Ghats \\
\hline 31. & Gymnacranthera canarica (King) Warb & MYRISTICACEAE & Vulnerable (IUCN) \\
\hline 32. & Holigarna arnottiana Hook. f. & ANACARDIACEAE & Endemic to W. Ghats \\
\hline 33. & Holigarna ferruginea Marchand & ANACARDIACEAE & Endemic to W. Ghats \\
\hline 34. & Holigarna grahamii (Wight) Kurz & ANACARDIACEAE & Endemic to W. Ghats \\
\hline 35. & Holigarna nigra Bourd. & ANACARDIACEAE & Endemic to W. Ghats \\
\hline 36. & Hopea canarensis Hole & DIPTEROCARPACEAE & Endangered (IUCN) \\
\hline 37. & Hopea parviflora Beddome & DIPTEROCARPACEAE & Endemic to W. Ghats \\
\hline 38. & Hopea ponga (Dennst.) Mabb. & DIPTEROCARPACEAE & Endemic to W. Ghats \\
\hline 39. & Hopea racophloea Dyer & DIPTEROCARPACEAE & Endemic to W. Ghats \\
\hline 40. & Humboldtia brunonis Wallich & CAESALPINIACEAE & Endemic to W. Ghats \\
\hline 41. & Hydnocarpus pentandrus (Buch.-Ham.) Oken & FLACOURTIACEAE & Endangered (IUCN) \\
\hline 42. & Hymenodictyon obovatum Wallich & RUBIACEAE & Endemic to W. Ghats \\
\hline 43. & Ilex malabarica Beddome & AQUIFOLIACEAE & Endemic to W. Ghats \\
\hline 44. & Ixora brachiata Roxb. & RUBIACEAE & Endemic to W. Ghats \\
\hline 45. & Kingiodendron pinnatum (DC.) Harms & CAESALPINIACEAE & Endangered (IUCN) \\
\hline 46. & Knema attenuata (Hook. f. \& Thomson) Warb. & MYRISTIC & $\begin{array}{l}\text { Lower Risk/least concern } \\
\text { (IUCN) }\end{array}$ \\
\hline 47. & Kunstleria keralensis C.N. Mohanan \& Nair & PAPILIONACEAE & Endemic to W. Ghats \\
\hline 48. & Lagerstroemia microcarpa Wight & LYTHRACEAE & Endemic to W. Ghats \\
\hline 49. & Litsea laevigata (Nees) Gamble & LAURACEAE & Endemic to W. Ghats \\
\hline 50. & Madhuca insignis (Radlkofer) H.J. Lam & SAPOTACEAE & $\begin{array}{l}\text { Critically } \\
\text { (IUCN) }\end{array}$ \\
\hline 51. & Mallotus stenanthus Muell.-Arg. & EUPHORBIACEAE & Endemic to W. Ghats \\
\hline 52. & Meiogyne pannosa (Dalz.) Sinclair & ANNONACEAE & Endemic to W. Ghats \\
\hline 53. & Memecylon malabaricum (C.B. Clarke) Cogn. & MELASTOMATACEAE & Endemic to W. Ghats \\
\hline 54. & Memecylon talbotianum Brandis & MELASTOMATACEAE & Endemic to W. Ghats \\
\hline 55. & Moullava spicata (Dalz.) Nicolson & CAESALPINIACEAE & Monotypic, Non-endemic \\
\hline 56. & Myristica magnifica Bedd. & MYRISTICACEAE & Endangered (IUCN) \\
\hline 57. & Myristica malabarica Lam. & MYRISTICACEAE & Vulnerable (IUCN) \\
\hline 58. & Nothopegia racemosa (Dalz.) Ramam. & ANACARDIACEAE & Endemic to W. Ghats \\
\hline 59. & Ochlandra scriptoria (Dennst.) C. Fischer & GRAMINEAE & Endemic to W. Ghats \\
\hline 60. & Ochlandra travancorica Benth. ex Gamble & GRAMINEAE & Endemic to W. Ghats \\
\hline 61. & $\begin{array}{l}\text { Ochreinauclea missionis (Wallich ex G. Don) } \\
\text { Ridsd. }\end{array}$ & RUBIACEAE & Vulnerable (IUCN) \\
\hline 62. & Otonephelium stipulaceum (Beddome) Radlk. & SAPINDACEAE & Endemic, Monotypic \\
\hline 63. & Pandanus unipapillatus Dennst. & PANDANACEAE & Endemic to W. Ghats \\
\hline 64. & Pinanga dicksonii (Roxb.) Blume & PALMAE & Endemic to W. Ghats \\
\hline 65. & Pittosporum dasycaulon Miq. & PITTOSPORACEAE & Endemic to W. Ghats \\
\hline 66. & Poeciloneuron indicum Beddome & GUTTIFERAE & Endemic to W. Ghats \\
\hline 67. & Polyalthia fragrans (Dalz.) Beddome & ANNONACEAE & Endemic to W. Ghats \\
\hline 68. & Psychotria dalzellii Hook. f. & RUBIACEAE & Endemic to W. Ghats \\
\hline 69. & Psychotria flavida Talbot & RUBIACEAE & Endemic to W. Ghats \\
\hline 70. & Pterospermum reticulatum Wight \& Arn. & STERCULIACEAE & Endemic to W. Ghats \\
\hline 71. & Spatholobus purpureus Benth. ex Baker & PAPILIONACEAE & Endemic to W. Ghats \\
\hline 72. & Syzygium kanarense (Talbot) Raizada & MYRTACEAE & Endemic to W. Ghats \\
\hline 73. & Syzygium laetum (Buch.-Ham.) Gandhi & MYRTACEAE & Endemic to W. Ghats \\
\hline 74. & Syz. & MYRTACF & $\begin{array}{l}\text { Critically } \\
\text { (IUCN) }\end{array}$ \\
\hline 75. & Tabernaemontana heyneana Wallich & APOCYNACEAE & Endemic to W. Ghats \\
\hline 76. & Trewia polycarpa Benth. & EUPHORBIACEAE & Endemic to W. Ghats \\
\hline 77. & Vateria indica $\mathrm{L}$. & DIPTEROCARPACEAE & Vulnerable (IUCN) \\
\hline 78. & Ventilago bombaiensis Dalz. & RHAMNACEAE & Endemic to W. Ghats \\
\hline 79. & Vepris bilocularis (Wight \& Arn.) Engl. & RUTACEAE & Endemic to W. Ghats \\
\hline
\end{tabular}



with Special Refernce to Endemic and Threatened Plants as an Ex-Situ Conservation Measure

Plate 1: Photographs of some of the endemic plants introduced in the arboretum
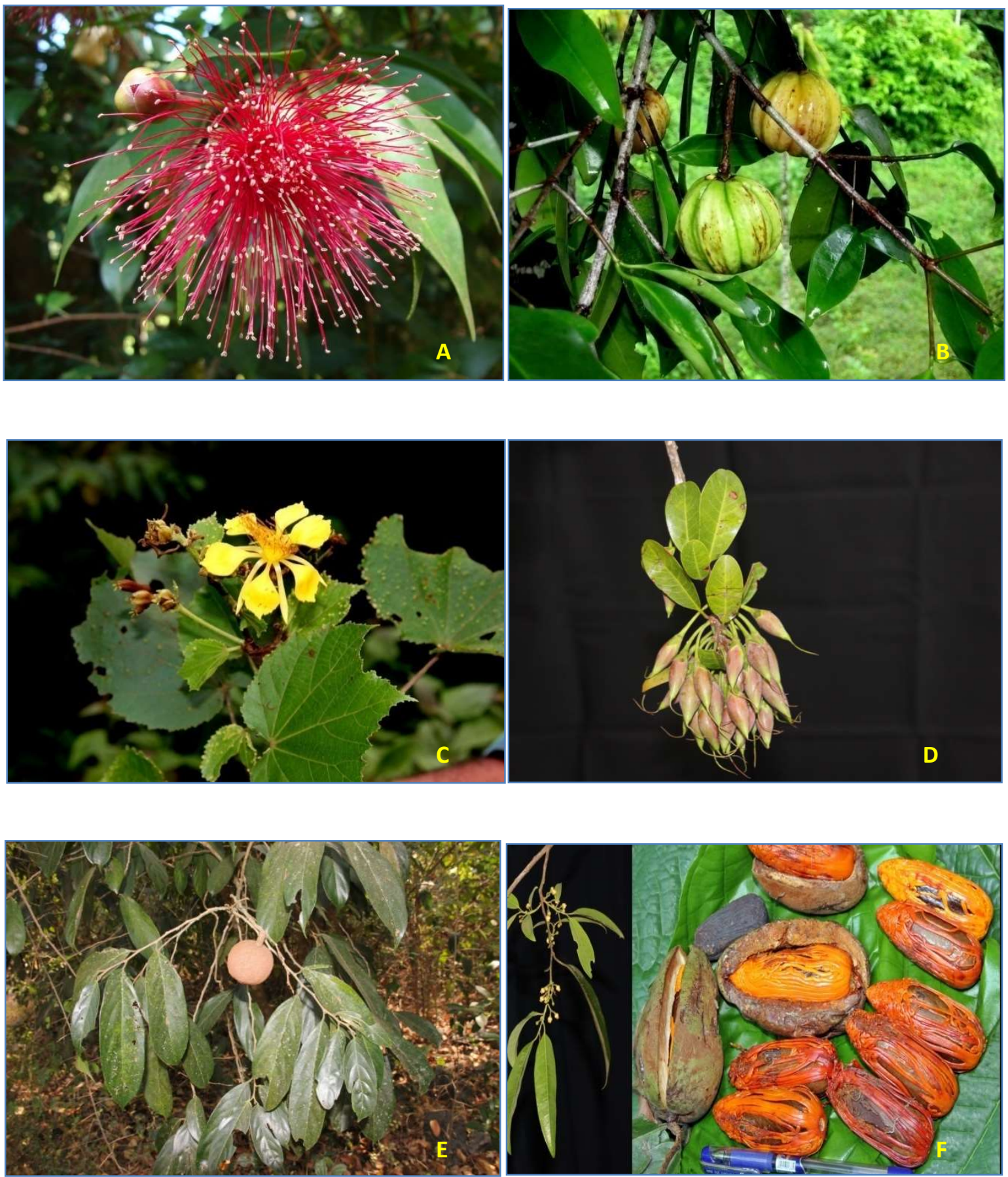

A. Syzygium laetum (Buch.-Ham.)(Image (C) Ramakrishna Marati)

B. Garcinia gummigutta (L.) N. Robson (Image (C) Ramakrishna Marati)

C. Erinocarpus nimmonii J.Graham (Image (C) Ramakrishna Marati)

D. Madhuca insignis (Radlkofer) H.J. Lam.(Image ( Ramakrishna Marati)

E. Hydnocarpus pentandrus (Buch.-Ham.) Oken (Image @ Ramakrishna Marati)

F. Myristica malabarica Lam.(Image $\mathbb{C}$ Ramakrishna Marati) 
Plate 1: Photographs of some of the endemic plants introduced in the arboretum (Contd.)
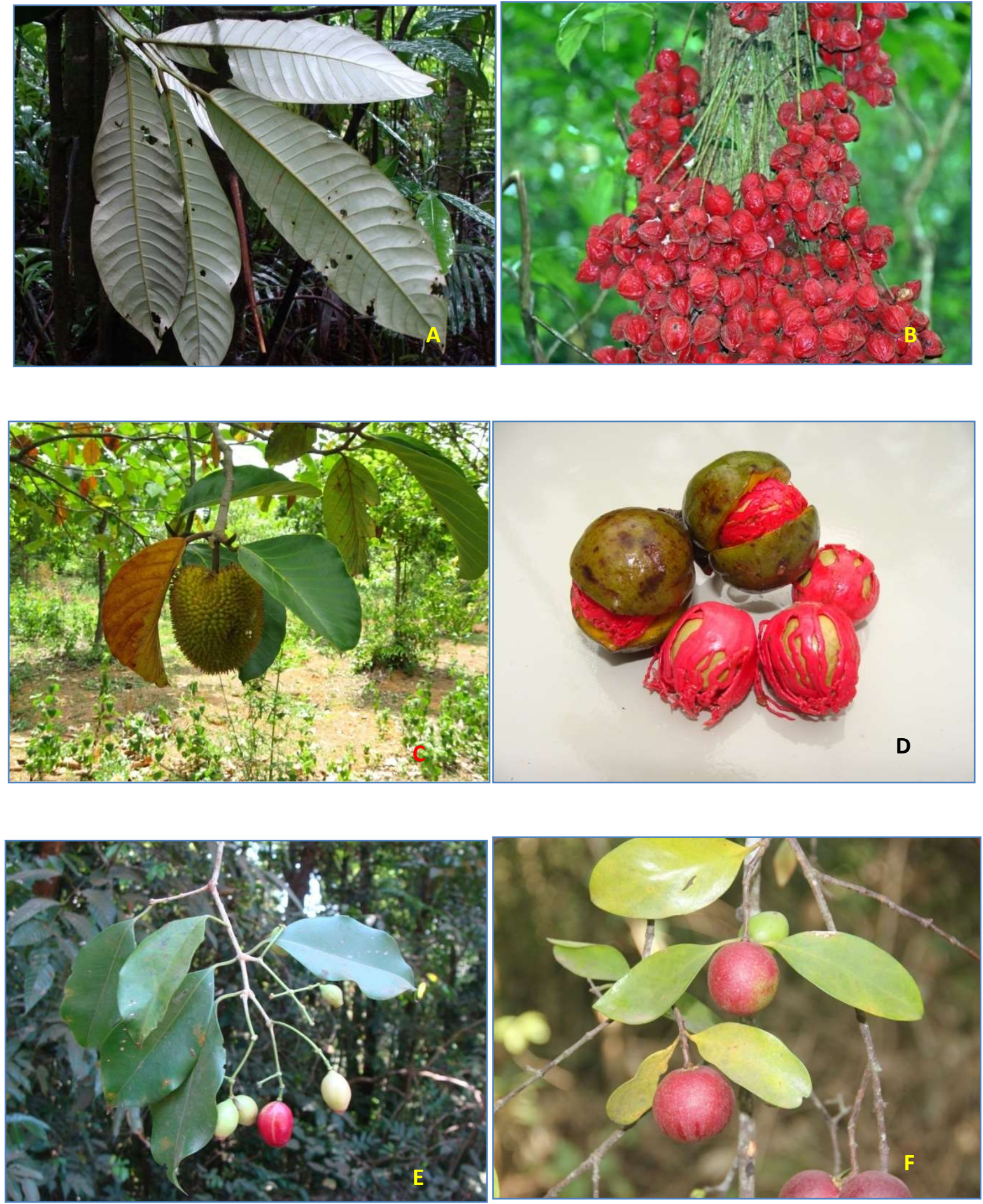

A. Myristica fatua Houtt. var. magnifica (Beddome) Sinclair(Image C Ramakrishna Marati)

B. Baccaurea courtallensis Muell.-Arg.(Image (C) Ramakrishna Marati)

C. Artocarpus hirsutus Lam. (Image (C) Ramakrishna Marati)

D. Gymnacranthera canarica (King) Warb(Image (C) Ramakrishna Marati)

E. Syzygium kanarense (Talbot) Raizada(Image (C Ramakrishna Marati)

F. Garcinia indica (Thouars) Choisy (Image (C) Ramakrishna Marati) 